\title{
PROSES BERPIKIR SISWA TUNA GRAHITA DALAM MENYELESAIKAN MASALAH BILANGAN BULAT POSITIF BERDASARKAN TEORI ASIMILASI AKOMODASI
}

\author{
Lady Agustina \\ Program Studi Pendidikan Matematika, Universitas Muhammadiyah Jember \\ Email: ladyagustina@unmuhjember.ac.id
}

\begin{abstract}
Abstrak:
Siswa tuna grahita ringan memiliki keterbatasan dalam hal intelektual dan mengalami kesulitan dalam mempelajari penjumlahan dan pengurangan bilangan bulat 1-50. Untuk mengatasi kesulitan tersebut, maka peneliti dan guru kelas bersama-sama harus mampu mengetahui profil belajarnya, sehingga akan menemukan suatu solusi untuk mengatasi kesulitan siswa tuna grahita ringan tersebut. Tujuan dari penelitian ini adalah untuk mendeskripsikan proses berpikir siswa tuna grahita ringan dalam menyelesaikan soal penjumlahan dan pengurangan bilangan bulat yang dikaitkan dengan penggunaan media yang sering siswa jumpai melalui observasi. Proses berpikir yang dimaksud mengacu pada indikator tahapan piaget yaitu terjadinya disequilibrium, asimilasi, atau akomodasi. Jenis penelitian ini adalah deskriptif kualitatif. Subjek pada penelitian ini adalah dua siswa tuna grahita ringan kelas V MI Al Kawtsar Panti Jember, Jawa Timur, Indonesia.Tahapan-tahapan pada penelitian ini adalah 1. pemberian soal, 2. penentuan kecenderungan sesuai teoridan 3. wawancara. Adapun hasil yang diperoleh pada penelitian ini adalah kedua subjek mengalami keadaan disequilibrium pada saat awal pengerjaan soal. Kedua subjek tidak dapat memahami kalimat pada soal dan menjawab soal secara inkonsisten. Selain itu, kedua subjek hanya diam ketika tidak tahu maksud pertanyaan peneliti tentang pemahaman soal. Subjek mengalami asimilasi ketika subjek langsung dapat menjawab pertanyaan dari peneliti dengan spontan tanpa menghiraukan salah atau benar jawabannya. Kedua subjek tersebut juga mengalami akomodasi ketika terdiam sejenak sebelum menjawab dengan benar pertanyaan dari peneliti. Sehingga kecenderungan siswa tuna grahita ringan dalam menyelesaikan soal penjumlahan dan pengurangan bilangan bulat adalah mengalami ketiga tahapan berfikir menurut piaget meskipun itu dilakukan dengan pendekatan yang maksimal dari seorang peneliti.
\end{abstract}

Kata Kunci: Proses Berfikir, Tuna Grahita Ringan, Asimilasi, Akomodasi

\begin{abstract}
:
Students with low mental disabilities have limitations in intellectual matters and have difficulty in learning the addition and subtraction of integers 1-50. The purpose of this study was to describe the thought process of low mentally disabled students in solving integer and subtraction problems associated with media use that students often encounter through observation. The thought process referred to refers to the Piaget stage indicator, namely the occurrence of disequilibrium, assimilation, or accommodation. This type of research is qualitative descriptive. The subjects in this study were two students with low mental disabilities in class V MI Al Kawtsar Panti Jember, East Java, Indonesia. The stages in this study are 1. giving questions, 2. determining trends according to theory and 3 . interviewing. Both subjects cannot understand the sentence in the question and answer the question inconsistently. In addition, the two subjects were only silent when they did not know the purpose of the researchers' questions about understanding the questions. Subjects experience assimilation when the subject can immediately answer questions from the researcher spontaneously regardless of the correct or correct answer. The two subjects also experienced accommodation when they paused for a moment before answering correctly the questions from the researcher. So that the tendency of low mentally disabled students to solve the addition and reduction problems of integers is to experience the three stages of thinking according to Piaget even though that is done with a maximum approach from a researcher.
\end{abstract}

Keywords: Thinking Process, Low Disability, Assimilation, Accommodation 


\section{Pendahuluan}

Setiap anak yang terlahir di dunia ini unik dan luar biasa dengan memiliki kelebihan dan kekurangan, sehingga setiap anak berbeda satu dengan yang lain. Sebagian anak terlahir sempurna dan beberapa diantaranya mempunyai perbedaan yang kita sebut berkebutuhan khusus (Libal, 2004). Anak yang memiliki keterbelakangan mental (berkebutuhan khusus) tidak berarti kehilangan fungsi, misalnya anak yang menggunakan kursi roda tidak berarti dia kehilangan fungsi mobilitasnya. Kita tidak boleh mengabaikan nilai - nilai kehidupan lainnya yang berkaitan dengan mereka (Jeon, 2018).

Pendidikan memainkan peran utama dalam perkembangan mental anak (Spadek \& Saracho, 2014; Galassi, 2017; Davies, Janus, Duku, Gaskin, 2016; Fauth, Decristan, Rieser, Klieme \& Buttner, 2014; Chareka, 2017). Ditahap awal pengalaman belajar, anak yang berkebutuhan khusus mungkin merasa malu dan asing bagi siapa saja yang tidak bisa mengembangkan atau tidak memiliki ketrampilan mengatasinya (Olson, 2014)

Perbedaan kognitif yang terkait dengan ketidakmampuan belajar merupakan hambatan yang dihadapi oleh siswa berkebutuhan khusus di tingkat Sekolah Dasar (Fullaton \& Duquette). Sangat menarik untuk mengidentifikasi perubahan dalam pembangunan pemikiran siswa (Mikerova, Sergeeva, Mardirosova, Kazantseva \& Karpenko, 2018). Pemrosesan lambat dan buruk membaca, menulis dan ejaan mempengaruhi fungi akademik (Erten, 2011; Harrison, Larochette \&Nichols, 2007; Ryan, 2007; Stage \& Milne, 1996).

Siswa yang berkebutuhan khusus lebih memiliki kendala yang lebih besar dibandingkan dengan anak yang normal, maka dari itu dengan perbedaan ini keberhasilan di bidang akademik mereka membutuhkan pemeriksaan lebih lanjut (Wasielewski, 2016)

Anak Berkebutuhan Khusus (ABK) adalah anak-anak yang menandakan adanya kelainan khusus. ABK mempunyai karakteristik yang berbeda antara satu dengan lainnya. Salah satu $\mathrm{ABK}$ yang mendapatkan layanan di Indonesia anak yang memiliki keterbatasan mental (tuna grahita). Pada umumnya, masyarakat kurang memberikan perhatian khusus pada anak penderita tuna grahita. Menurut Sigit (2009) selama ini perhatian masyarakat sebatas kepada cacat fisik seperti tuna netra, tuna rungu, dan tuna daksa. Hal ini dikarenakan sekilas anak tuna grahita tidak berbeda dengan anak normal.Perkembangan fisik anak tuna grahita dapat sangat baik, namun psikomotornya sangat lambat. Akibatnya masyarakat tidak memberikan perhatian lebih banyak dibandingkan cacat fisik. Padahal anak tuna grahita membutuhkan pendampingan sepanjang hidupnya.

American Assosiation on Mental Retardation (AAMR) (Soendari, 2006) mengklasifikasikan tingkat kecerdasaan tuna grahita menjadi 4 , yaitu tuna grahita ringan (IQ 55-70), sedang (IQ 40-54), berat (IQ 25-39), dan sangat berat (IQ $\leq 24$ ). Tuna grahita ringan disebut juga dengan istilah debildan mampu didik. Menurut American Association on Mental Retardation dalam Special Education in Ontario Schools (Sigit, 2009) mampu didik atau educable artinya anak tuna grahita ini masih mempunyai kemampuan dalam akademik setara dengan anak reguler pada kelas 5 Sekolah Dasar. Sehingga perkembangan kognitif anak tuna grahita terhenti pada tahap operasional konkret.Menurut Piaget (Delphie, 2009) pada tahap operasional konkret anak sudah dapat menambah, mengurangi, mengubah serta memungkinkan untuk dapat memecahkan masalah secara logis. Jika demikian, kemampuan anak tuna grahita ringan berusia 14 tahun akan tetap pada tahap operasional konkret pada usia 7 sampai 11 tahun.

Bagi sebagian besar siswa normal, matematika merupakan mata pelajaran yang dianggap sulit dan susah dipahami karena matematika bersifat abstrak. Siswa tuna grahita ringan juga mengalami hal yang sama. Siswa tuna grahita ringan memiliki keterbatasan dalam hal intelektual, sehingga merekasemakin sulit untuk memahami mata pelajaran matematika. Siswa tuna grahita sering memiliki masalah dalam generalisasi 
informasi dari satu pengaturan ke yang lain. Cara alternatif untuk mengajarkan generalisasi adalah mengajar siswa memecahkan masalah yang berkaitan dengan kehidupan sehari - hari mereka dan untuk memperkuat prilaku yang akan terjadi di lingkungan mereka (Nazirzedah, Cagilaty \& Karasu, 2017).

Siswa melakukan proses berpikir ketika memecahkan masalah (Frenke \&Kezemi, 2001). Dalam proses berpikir ada proses antara informasi yang masuk dan skema (struktur kognitif) di otak seseorang (Subanji \& Supratman, 2015). Guru dapat merancang pembelajaran yang sesuai dengan proses berpikir siswa dengan mengetahui jenis kesalahan siswa dalam memecahkan suatu masalah melalui pelacakan proses (Sukoriyanto, Nusantara, Subanji \& Candra, 2016).

Proses berpikir yang dimaksud dalam penelitian ini mengacu pada indikator dari tahapan kognitif menurut Piaget, yaitu terjadinya disequilibrum, asimilasi dan akomodasi. Disequilbrium diperlukan untuk mendorong siswa terlibat dan menciptakan daripada hanya melakukan atau mengeksekusi (Santos \&Mclntyce, 2016). Siswa mengalami disequilibrum jika siswa bingung dari awal sampai akhir ketika mengerjakan soal penjumlahan dan pengurangan.Proses kognitif yang terjadi saat seseorang mengintegrasikan persepsi, konsep atau pengalaman baru ke dalam skema yang ada dalam pikiran disebut asimilasi (Subanji \& Supratman, 2015). Apabila siswa menjawab spontan pada saat diberikan soal penjumlahan dan pengurangan maka siswa mengalami asimilasi. Sementara akomodasi adalah proses mengintegrasikan stimulus baru melalui penciptaan skema baru atau mengubah skema lama untuk menyesuaikan dengan masalah yang dihadapi (Subanji \& Supratman, 2015). Dalam penelitian ini, jika siswa berfikir sejenak atau diam sesaat ketika mengerjakan soal ataupun waktu wawancara, maka siswa mengalami akomodasi dalam diri siswa.

Adapun tujuan dari kegiatan penelitian ini adalah untuk mendeskripsikan proses berpikir siswa tuna grahita ringan dalam menyelesaikan soal penjumlahan dan pengurangan bilangan bulat yang dikaitkan dengan penggunaan media. Kegiatan penelitian ini memberikan manfaat kepada guru untuk mengetahui proses berpikir siswa tuna grahita ringan yang dididiknya, sehingga guru akan menentukan solusi dari kelemahan-kelemahan siswa dalam belajar matematika khususnya penjumlahan.

\section{Metode Penelitian Jenis Penelitian}

Penelitian ini merupakan penelitian deskriptif kualitatif yang bertujuan untuk mendeskripsikan bagaimana proses berpikir anak tuna grahita ringan ketika menyelesaikan masalah bilangan bulat. Proses berpikir siswa yang dimaksud pada penelitian ini adalah cara berfikir atau aktivitas mental siswa tuna grahita ringan ketika menyelesaikan soal penjumlahan dan pengurangan bilangan bulat. Penelitian ini dilakukan pada siswa kelas V MI Al Kawtsar Panti Jember.

\section{Subjek Penelitian}

Subjek dalam penelitian ini adalah dua orang siswa kelas VMI Al Kawtsar Panti Jember yang tergolong dalam tuna grahita ringan.Teknik pemilihan subjek menggunakan teknik purposive sampling, dimana peneliti menentukan pengambilan sampel dengan cara menetapkan ciri - ciri khusus yang sesuai dengan tujuan penelitian sehingga diharapkan dapat menjawab permasalahan penelitian (Coben, Marion \& Marrison, 2007).

\section{Teknik Pengumpulan Data}

Instrumen utama dalam penelitian ini adalah peneliti sendiri. Instrumen bantu dalam penelitian ini adalah soal matematika non rutin tentang penjumlahan dan pengurangan bilangan bulat dalam bentuk essay.

Teknik pengumpulan data menggunakan teknik wawancara dan tes. Kedua subjek diberikan soal tes yang berisi soal non rutin dalam bentuk soal cerita tentang penjumlahan dan pengurangan bilangan bulat. Peneliti melakukan wawancara mendalam kepada kedua subjek untuk mengetahui secara mendalam proses berpikir mereka. Analisis data dilakukan 
dengan semua data yang diperoleh baik dari hasil subjek menyelesaikansoal cerita penjumlahan dan pengurangan bilangan bulat maupun dari wawancara, dianalisis oleh peneliti sesuai dengan teknis yang digunakan.
Indikator proses berfikir siswa dalam menyelesaikan soal penjumlahan dan pengurangan bilangan bulat dengan menggunakan media permen dan gambar disesuaikan dengan tahapan Piaget dapat dilihat pada Tabel 1.

Tabel 1. Indikator Profil Berpikir Sesuai dengan Tahapan Piaget

Istilah dalam Berpikir Indikator

a. Siswa terlihat bingung memahami sebagian kalimat pada soal/masalah yang diberikan peneliti.

b. Siswa masih bingung menyebutkan bilangan/angka mana sajakah yang terdapat dalam soal cerita itu.

c. Siswa masih bingung operasi yang tepat untuk menyelesaikan soal/masalah yang diberikan peneliti.

d. Siswa masih bingung menyebutkan apa yang diketahui dan apa yang ditanya dari soal cerita yang diberikan peneliti.

Disequilibrium

e. Siswa hanya diam ketika diberi petunjuk untuk memperagakan soal cerita pada alat peraga yang telah disediakan

f. Siswa hanya mengatakan "tidak tahu"atau mengajukan pertanyaan tanpa melakukan apapun saat diberi petunjuk untuk memperagakan soal cerita pada alat peraga yang telah disediakan

g. Siswa masih bingung untuk membacakan hasil pekerjaannya

h. Siswa tidak ingin membacakan hasil pekerjaannya

i. Siswa masih keadaan bingung ketika diberi petunjuk untuk menuliskan kalimat matematika

a. Siswa dapat menjawab dengan spontan baik salah maupun benar bilangan/angka mana sajakah yang terdapat pada soal.

b. Siswa dapat menjawab dengan spontan baik salah maupun benar operasi yang tepat untuk menyelesaikan soal/masalah yang diberikan peneliti.

c. Siswa dapatmenjawab dengan spontan baik salah maupun benar apa saja yag diketahui dan apa yang ditanyakan dari soal

Asimilasi cerita yang diberikan peneliti.

d. Siswa dengan spontan baik salah maupun benar menjumlah gambar burung dan menurangi permen setelah diberi petunjuk untuk memperagakan soal cerita pada alat peraga yang telah disediakan

e. Siswa dapat memperagakan soal cerita pada alat peraga yang telah disediakan baik salah maupun benar sambil bercerita dengan bahasanya sendiri

a. Siswa diam sesaat sebelum menjawab benar bilangan/angka mana sajakah yang terdapat pada soal.

b. Siswa diam sesaat sebelum menjawab benar operasi yang tepat untuk menyelesaikan soal/masalah yang diberikan peneliti.

Akomodasi

c. Siswa diam sesaat sebelum menjawab benar bilangan mana yang dijumlah dan bilangan mana yang dikurangi.

d. Siswa diam sesaat sebelum menjawab dengan benar berkaitan dengan apa yang diketahui dan apa yang ditanyakan. 


\section{Hasil dan Pembahasan Hasil}

Pengambilan data diawali dengan memilih siswa tuna grahita ringan yang akan dijadikan subjek penelitian. Berdasarkan teknik purposive sampling akan diperoleh dua subjek untuk selanjutnya dilakukan analisis secara mendalam mengenai proses berpikir pada saat menyelesaikan soal cerita penjumlahan dan pengurangan bilangan bulat.

Untuk memudahkan dalam menganalisis data tersebut, maka digunakan inisial yaitu : (1) Inisial "P" untuk peneliti; (2) Inisial "HS" sebagai subjek pertama dan (3) Inisial "MM" sebagai subjek kedua Berikut adalah jawaban subjek HS pada soal penjumlahan dan pengurangan:

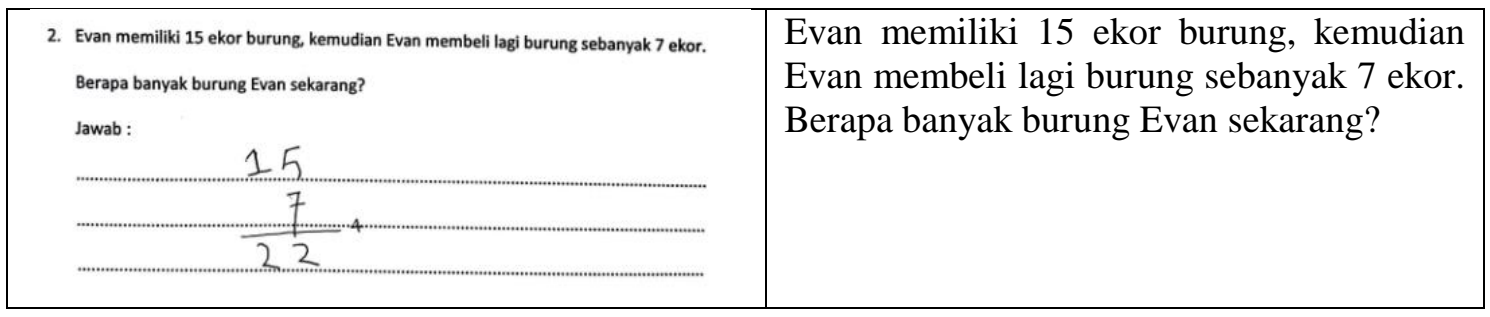

Gambar 1. Jawaban Subjek HS pada Soal Penjumlahan

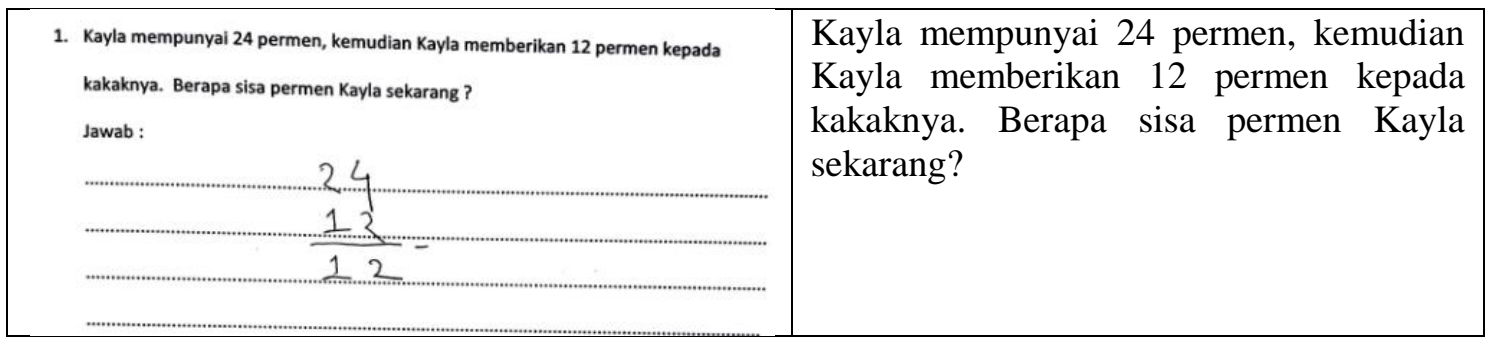

Gambar 2. Jawaban Subjek HS pada Soal Pengurangan

Subjek HS cenderung menuliskan jawabannya dengan cara bersusun. Untuk soal penjumlahan bilangan bulat berikut cuplikan wawancara dengan subjek HS.

Soal tes: Evan memiliki 15 ekor burung, kemudian Evan membeli lagi burung sebanyak 7 ekor. Berapa banyak burung Evan sekarang?

$\begin{array}{ll}\mathrm{P} & \quad \text { : Bagaimana HS soal ini } \\ \mathrm{HS} & \text { : (membaca dengan terbata - bata } \\ & \text { dan sedikit bergumam, dan mulai } \\ & \text { bingung setelah membaca) } \\ \mathrm{P} & : \text { (membaca ulang dan sedikit } \\ & \text { diterjemahkan ke bahasa sehari - } \\ & \text { hari subjek) soal tentang apa itu } \\ & \text { HS? } \\ \mathrm{HS} & \text { : ditambahkan burungnya } \\ \mathrm{P} & \text { : iya betul sekali pinter HS } \\ \mathrm{HS} & \text { : saya pakai apa bu guru? } \\ \mathrm{P} & \text { : pakai apanya? } \\ \mathrm{HS} & \text { : yang seperti MM saya mau } \\ & \text { dengan permen ya bu guru }\end{array}$

P : ohh, kamu pakai gambar burung saja ya karena kan evan punya burung

HS : (tersenyum)

$\mathrm{P} \quad$ : ayo HS di hitung ya

HS : iya bu guru (mengambil gambar burung dan kemudian mulai menghitung)

$\mathrm{P} \quad$ : bagaimana HS?

HS : sebentar bu

$\mathrm{P} \quad$ : burungnya kebanyakan tah $\mathrm{HS}$

HS : iya bu (sambil melihat dan kelihatan bingung lagi)

$\mathrm{P} \quad$ : ya sudah burungnya dilingkari saja yang punya Evan tadi

HS : (mulai melingkari 15 burung dan menambah melingkari 7 gambar burung lagi)

$\mathrm{P} \quad$ : sudah HS?

HS : sudah bu

$\mathrm{P}$ : sekarang berapa jumlah burungnya

HS : (menghitung dengan terbata bata) dua puluh dua bu 
P $\quad$ : iya betul sekali. Tulis ya sekarang dikertasnya tadi

HS : iya bu, pake susun boleh bu?
$\mathrm{P} \quad$ : iya boleh gak apa - apa

Berikut adalah jawaban subjek MM

pada soal penjumlahan dan pengurangan

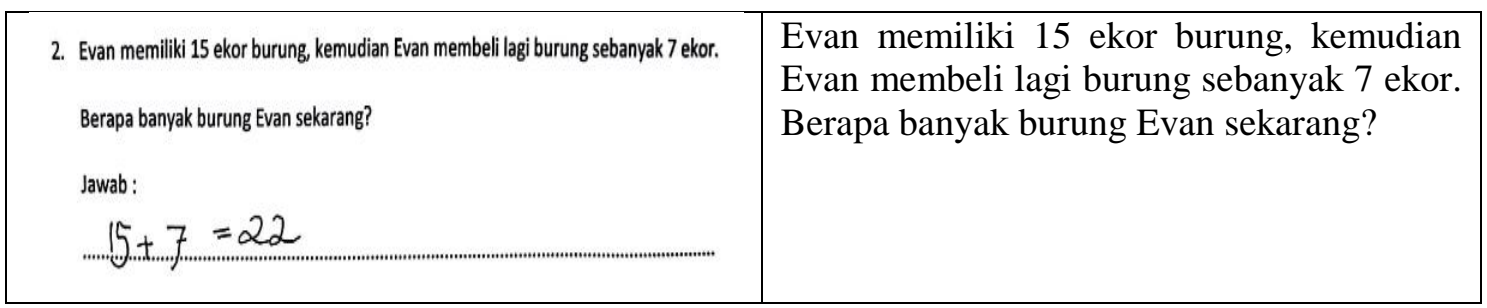

Gambar 3. Jawaban Subjek MM pada Soal Penjumlahan

1. Kayla mempunyai 24 permen, kemudian Kayla memberikan 12 permen kepada
kakaknya. Berapa sisa permen Kayla sekarang?
Jawab:
$24-12=12$

Gambar 4. Jawaban Subjek MM pada Soal Pengurangan

Subjek MM cenderung menuliskan jawabannya dengan cara mendatar. Berikut cuplikan wawancara dengan subjek MM pada soal pengurangan bilangan bulat.

Soal tes: "Kayla mempunyai 24 permen, kemudian Kayla memberikan 12 permen kepada kakaknya. Berapa sisa permen Kayla sekarang?"

$\mathrm{P}$ : bagaimana MM bisa?

P : coba ibu bantu.(menunjukkan alat peraga permen). Coba $M M$ dibaca lagi pelan - pelan soalnya. Kalau bingung bisa pakai permen ini nanti menghitungnya

MM : (membaca dengan terbata - bata soal tersebut)

P : (membaca ulang dan sedikit diterjemahkan ke bahasa sehari hari subjek) di soal disuruh apa berarti MM?

MM : dikurangi bu karena permennya diberikan kepada kakaknya

P : betul, pinter MM. Nah sekarang coba MM hitung ya

MM : pake permen ini ya bu

$\mathrm{P} \quad$ : boleh, silahkan

MM : (menata permen sejumlah 24 biji di mejanya kemudian mengambil sejumlah 12 permen, )
Kayla mempunyai 24 permen, kemudian Kayla memberikan 12 permen kepada kakaknya. Berapa sisa permen Kayla sekarang?

P : nah MM bagaimana sekarang permennya sisa berapa?

MM : (menghitung sambil bergumam). Sisa dua belas bu

$\mathrm{P} \quad$ : bagus, sekarang tulis ya jawaban kamu dikertas itu

MM : (menulis jawaban langsung angka dengan cara biasa mendatar)boleh begini bu?

$\mathrm{P} \quad$ : iya boleh

Proses berpikir memerlukan waktu untuk subjek memahami masalah pada soal. Ketika diberikan soal subjek tidak langsung menuliskan jawaban mereka ditambah lagi kemampuan membaca mereka yang kurang sehingga peneliti membantu mereka dengan memberikan alat peraga juga.

\section{Pembahasan}

Dari hasil wawancara yang diperoleh awal mereka mengalami kebingungan saat mau mengerjakan soal tersebut ditambah lagi kedua subjek kemampuan membacanya kurang dan juga belum bisa memahami soal dengan baik, saat itulah kedua subjek mengalami disequilbrium. Saat peneliti mencoba membacakan ulang dan mengartikan ke dalam bahasa kesehari - harian mereka, kedua subjek mulai memahami apa isi soal yang peneliti berikan, disinilah kedua 
subjek mengalami tahap asimilasi. Kemudian dengan bantuan alat peraga berupa permen dan gambar burung subjek mulai menghitung dan menjawab soal. Mereka juga menggunakan jari mereka untuk menghitung soal tersebut, sehingga dengan spontan mereka bisa menjawab soal yang peneliti berikan, disinilah mereka mengalami tahap akomodasi.

Hasil yang diperoleh dalam penelitian ini sejalan dengan hasil penelitian Sigit pada tahun 2009 yang menyatakan bahwa siswa tuna grahita memiliki keterbatasan dalam hal intelektual, sehingga siswa tuna grahita semakin sulit untuk memahami mata pelajaran matematika. Karena kecerdasan intelektual yang dimiliki siswa tuna grahita terbatas, maka guru hendaknya melakukan penjelasan berulang - ulang sehingga siswa memahami apa yang disampaikan oleh guru (Utami, Sujadi \& Riyadi, 2014)

Pembelajaran matematika yang diberikan kepada siswa tuna grahita ringan sebaiknya perlu menggunakan benda benda nyata sehingga memudahkan siswa dalam mengabstrasikan konsep matematika. Siswa tuna grahita ringan lebih mudah dalam mengingat sesuatu yang berbentuk kongkret sehingga mudah bagi mereka untuk merepresentasikan apayang ada dalam pikiran mereka. Lingkungan yang baik memungkinkan peningkatan dengan cepat siswa tuna grahita ringan terhadap rangsangan dengan memperhatikan objek tertentu (Sahin \& Cimen, 2011)

Hal tersebut juga sejalan dengan hasil penelitian Soendari tahun 2006 yang menyatakan bahwa terbatasnya kemampuan intelektual pada anak tuna grahita ringan membawakonsekuensi pada kesulitan mereka dalam mengikuti pelajaran akademik termasuk pelajaran matematika. Matematika sebagai pelajaran yang bersifat abstrak menyebabkan anak-anak tuna grahita ringan mengalami kesulitan dalam memahami konsep-konsep matematika, sehingga konsep-konsep matematika yang mereka pelajari di sekolah menjadi tidak fungsional.

\section{Simpulan dan Saran \\ Simpulan}

Berdasarkan hasil analisis dan pembahasan disimpulkan bahwa kedua subjek mengalami keadaan disequilibrium pada saat awal pengerjaan soal.Mereka tidak dapat memahami kalimat pada soal dan menjawab soal secara inkonsisten.Selain itu, kedua subjek hanya diam ketika tidak tahu maksud pertanyaan peneliti tentang pemahaman soal. Subjek mengalami asimilasi ketika subjek langsung dapat menjawab pertanyaan dari peneliti dengan spontan tanpa menghiraukan salah atau benar jawabannya. Kedua subjek tersebutjuga mengalami akomodasi ketika terdiam sejenak sebelum menjawab dengan benar pertanyaan dari peneliti.

\section{Saran}

Berdasarkan kesimpulan di atas, maka terdapat dua saran terkait perlakukan guru terhadap siswa tuna grahita ringan yaitu 1) Guru kelas ataupun pendamping perlu melakukan suatu kegiatan yang dapat memunculkan sebuah permasalahan ringan dengan alat peraga, supaya terjadi asimilasi serta akomodasi pada diri siswa tuna grahita ringan, meskipun pada awalnya terjadi disequilibrum, dan 2) Orang tua siswa tuna grahita ringan juga perlu melakukan pendekatan dengan cara mendampingi belajar dan memberikan sedikit permasalahan sehari-hari supaya anaknya terbiasa berfikir dan belajar khususnya matematika.

\section{Acknowledgement}

Ucapan trimakasih saya sampaikan kepada pihak LPPM Universitas Muhammadiyah Jember yang telah mendanai kegiatan penelitian ini.

\section{Daftar Pustaka}

Chareka, O. (2010). A Matter of Prior Knowledge: CanadianYoung Children's Conceptions about the Futurein the Global Community. International ElectronicJournal of Elementary Education, 2(2), 287304. 
Cohen, L; Marion, L \& Marrison, K. (2007). Research Methods In Education. Routledge

Davies, S., Janus, M., Duku, E., \& Gaskin, A. (2016). Usingthe Early Development Instrument to Examinecognitive and NonCognitive School Readiness Andelementary Student Achievement. Early ChildhoodResearch Quarterly, 35, 63-75.

Delphie, Bandi. (2009a). Pembelajaran Anak Berkebutuhan Khusus dalam Setting Pendidikan Inklusi. Klaten: PT Intan Sejati.

Delphie, Bandi. (2009b). Bimbingan Perilaku Adaptif (Anak dengan Hendaya Perkembangan Fungsional). Klaten: PT Intan Sejati.

Erten, O. (2011). Facing Challenges: Experiences of Young Women with Disabilities Attending a Canadian University. Journal of Postsecondary Education and Disability, 24, 101-114.

Fauth, B., Decristan, J., Rieser, S., Klieme, E., \& Büttner, G.(2014). Student ratings of teaching quality in primaryschool: Dimensions and prediction of studentoutcomes. Learning and Instruction, 29, 1-9.

Frenke ML, Kazemi E. (2001). Learning to Teach Mathematics: Focus on Student Thinking. Theory Into Practice. 40(2).102-109.

Fullarton, S \& Duquette, C. (2016). Experiences of Students With Learning Disabilities in Ontario Universities : A Case Study. International Journal of Spesial Education. 31(1). 55 - 66

Galassi, J. (2017). Strengths-based school counseling: Promotingstudent development and achievement. Routledge.

Harrison, A., Larochette, A., \& Nichols, E. (2007). Students with Learning Disabilities in Postsecondary Education: Selected Initial Characteristics. Exceptionality Education Canada, 17, 135-154.

Jeon, M. (2018). Meta - Analysis of Disability Simulation Research for Elementary Student in Korea. International Journal of Spesial Education. 33(1), 140 - 151

Libal, Autumn. (2009). Namaku Bukan Si Lamban Pemuda Penyandang Tunagrahita. Klaten: PT Intan Sejati.

Mikerova, G; Sergeeva,B; Mardirosova, G; Kazantseva, V; Karpenko, A. (2018). Learning Environment Affecting Primary School Student's Mental Development and Interest. International Electronic Journal of Elementary Education. 10(4). 407 412

Nazirzedah, MJ; Cagilaty, K \& Karasu, N. (2017). Developing A Gesture Based Game For Mentally Disabled People To Teach Basic Life Skills. International Conference Educational Technologies. 121 128

Olson, T. (2014, January). How Disability Simulations Promote Damaging Stereotypes. Braille Monitor, 57(1), 13

Ryan, J. (2007). Learning Disabilities in Australian Universities: Hidden, Ignored, and Unwelcome. Journal of Learning Disabilities,40. 436 442.

doi:10.1177/002221940704000507 01

Sahin, YG \& Cimen, FM. (2011). An Interactive Attention Board : 
Improving The Attention of Individuals With Autism and Mental Retardation. The Turkish Online Journal of Educational Technology. 10(1). 24 - 35

Santos, MC \& Mclntyce, MM. (2016). Toward a Technical Communication Made Whole : Disequlibrium, Creativity and Postpedagogy, Composition Forum 33

Sigit.(2009). Kesulitan Belajar, Lambat Belajar, TunaGrahita

Soendari, Tjutju. (2006). Pendekatan Realistik dalam Meningkatkan Kemampuan Matematika Anak Tuna grahita ringan di Sekolah Luar Biasa. Laporan Penelitian Mandiri. 1 (1)

Spodek, B., \& Saracho, O. N. (2014). Handbook of Researchon the Education of Young CHILDREN. Routledge.

Stage, F., \& Milne, N. (1996). Invisible Scholars: Students with Learning Disabilities. The Journal of Higher Education, 67, 426-445. doi:10.2307/2943806

Subanji R, Supratman AM. (2015). The Pseudo-Covariational Reasoning
Trought Processes in Constructing Graph Function of Reversible

Event Dynamics Based on Assimilation and Accomodation Frameworks. Research in Mathematical Education. J. The Korean Society of Mathematic Education. 19(1). 61-79.

Sukoriyanto S, Nusantara T, Subanji S, Chandra TD.(2016). Students Thinking Process in Solving Combination Problems Considered from Assimilation and Accomodation Framework. Academic Journal Educational Research and Reviews. 11(16). $1494-1499$

Utami, AD; Sujadi, I; Riyadi. (2014). Strategi Guru dalam Membelajarkan Matematika pada Materi Lingkaran kepada Anak Tuna Grahita (Studi Kasus pada Siswa Kelas VIII SLB Muhammadiyah Cepu). Jurnal Elektronik Pembeajaran Matematika. 2(8). 853 - 864

Wasielewski, LM. (2016). Academic Performance of Students with Disabilities in Higher Education : Insights from a Study of One Catholic College. Journal of Catholic Education.20(1). 136 151 